\title{
Exploration of factors impeding teacher education college students' speaking skills: The case of Jimma teachers college in Ethiopia
}

\author{
Dagne Tiruneh \\ Department of English Language and Literature, Jimma University, Ethiopia.
}

Received 28 January, 2014; Accepted 17 August, 2016

\begin{abstract}
This research was aimed at investigating factors which affect English as a Foreign Language (EFL) students' speaking skills in Jimma teacher Education College. The subjects of the study were second year EFL students and EFL teachers in the college. Among the 200 second year English Language students in the college, the researcher took $50 \%$ as the sample of the study using the simple random sampling technique. To take EFL teacher informants, the researcher employed comprehensive sampling since the number of the teachers was not large. The instruments used to gather data for the research were questionnaire, focus group discussion (FGD) and classroom observation. Among the students, $10 \%$ was involved in the FGD. In other words, two FGD consisting of ten students each was done with the EFL students. FGD was also conducted with EFL teachers. The researcher conducted one FGD in which 8 English language teachers participated. Classroom observation in which 5 EFL teachers were seen two times while they were teaching speaking skills was also conducted. The total number of observation conducted was 10. It was intended to investigate what the real speaking classroom looked like, how the students performed speaking skill tasks, to observe motivational strategies used by the EFL teachers in the speaking class/lesson, and to observe the type of speaking tasks used by the teachers to teach the skills. In order to analyze the data, the researcher used mixed approach whereby both qualitative and quantitative methods were utilized. The data which were collected by using questionnaire were analyzed quantitatively while those from FGD and the classroom observation were analyzed qualitatively. The results of the study indicated that speaking skill was the skill in which the students faced more problems. It had been found out that the main causes of the students' speaking problems were lack of exposure and opportunities to use English in and out of school, learners' poor background, lack of opportunities to practice, lack of confidence and motivation, and fear of speaking in front of their classmates and fear of making mistakes. On the basis of the findings of the study, the researcher had forwarded some recommendations.
\end{abstract}

Key words: Speaking skills, EFL, EFL teachers, speaking tasks, interaction, impeding factors.

\section{INTRODUCTION}

English is the language which is used widely in today's globalized world. It has become the Lingua Franca for communication, business, education and opportunities as a whole (Baker and Westrup, 2003). Among others 
things, economic advancement and technological developments played a pivotal role in placing English at the centre of communication. Researchers indicate that English language is a major medium of communication at a global arena across borders and is currently seen as the medium of communication in academic and business contexts (White, 2004; Farooqui, 2007; Cotter, 2007; Ramirez, 2010). Karahan (2007) also points out that English language is a leading foreign language which has a significant position in many areas of the glob as of the end of the Second World War. Since it is the language of international communication, English language has a decisive role to play in students' life, and learning the skills of the language is of paramount importance for them.

Skills taught in a language, on the whole, are categorized into four. These are listening, speaking, reading and writing. The four language skills are grouped into two. They are receptive skills and productive skills. Speaking is a productive skill which helps students to become communicatively competent. Accordingly, the goal of teaching speaking skills is the development of students' communicative efficiency. Learners are expected to make themselves understood using their current proficiency to the fullest and are expected to avoid confusion in the message due to wrong pronunciation, grammar, or vocabulary. They are also supposed to observe and identify the social and cultural rules that apply in each communication situation (Nagaraj, 2008).

According to Richards and Renandya (2002), a large number of the world's language students study English in order to develop their speaking proficiency. This indicates that speaking skill is important for people to be successful globally. Scholars in the areas of language studies indicate that among the four language skills, speaking plays the most vital role in students' success. Regarding the importance of speaking skill, Ur (1996) states the following:

... of all the four skills (listening, speaking, reading and writing), speaking seems intuitively the most important: people who know the language are referred to as "speakers" of that language, as if speaking included all other kinds of knowing; and many if not most foreign language learners are primarily interested in learning to speak.

From this, it is possible to figure out that speaking is the skill which students have to develop primarily in order to understand others and in order to be understood by others. In this way, they can make good social interaction which may lead them to success in every aspect of life. According to Cotter (2007), "learning speaking skills which let students communicate and interact in a meaningful and fruitful form (for example exchanging information, negotiating meaning, supporting ideas, facing oral defenses) is a means of encouraging students to use English Language as a tool for social interaction." This implies the fact that the knowledge of the skill transcends the limit of the life in the academic spectrum.

Speaking is used for many different purposes and each purpose involves different skills. Each of these different purposes for speaking implies knowledge of the rules that account for how spoken language reflects the context or situation in which the speech occurs. People speak to maintain existing social relationships and to make new ones. They also speak to pool and exchange information, and also ease the performance of transactions. So, there is a growing need in the modern world for people to communicate effectively through the medium of speech (McDonough and Shaw, 2003; Widdowson, 2003; Larsson and Olsson, 2008; Chaney and Burk, 1998; Nunan, 2003; Staab, 1992). In speaking class, students supposed to use English language to achieve a variety of social purposes: to entertain, to explain how something works, to provide information, to argue a position, to explore the inner world of the imagination. The skill is also used to make sense of the world to express and develop ideas on a range of topics from every day experience to the idea that are considered across all the areas of the curriculum.

Ramirez (2010) states that in order to succeed in their life in general and in their academic movement in particular, students need to be able to speak in English confidently with people from all walks of life: with those who are older or younger, with those in position of power, with their friends and family, with small and large group. Concerning the vitality of speaking skills for students, Cotter (2007) also contends that "if students have good speaking skills, they learn to interact with peers productively, to speak confidently in class discussion, to listen strategically, to read with comprehension and to write well-structured and coherent texts." In a similar token, White (2004) indicates that language is an integral part of learning, and speaking skills has a key role in classroom teaching and learning. In addition, scholars point out that the skills of speaking enables to encourage

E-mail: dagnetiru@yahoo.com.

Authors agree that this article remain permanently open access under the terms of the Creative Commons Attribution License 4.0 International License 
creativity, understanding and imagination; it is a means of solving problems, speculating, sharing ideas and making decisions; language builds friendship and enhances motivation through social interaction.

Despite the wider use of English Language, students encounter problems of listening and understanding English Language. They cannot express themselves in English and they fail to understand message when English is spoken. Emphasizing this thought, Elaine (2005) states that speaking is one of the ... four skills involved in using a foreign language, and as such is usually viewed as the most complex and difficult skill to master. In a related manner, Kang (2002), Bygate (1991), Baruah (1991), Brown and Yule (1983), Harmer (1984) and Celce-Murcia (2001) explain that learning to speak a foreign language in general, and EFL, in particular requires more than knowing its structural and semantic rules.

Furthermore, Geetha (2008) and Ur (1996) point out that the objective in any language classroom is to get the learners to learn the target language and use it instead of solely learning the rule of the language. This requires the students' active involvement in the learning process. This implies that speaking skill does not develop without the actual utilization of the target language for communicative purpose and without repetitive practice. In other words, speaking, like any language skill has to be learnt and practiced as it has various purposes.

Regarding the vitality of speaking skills, Kang (2002), Jack and Willy (2002) underline that learners must acquire knowledge of how native speakers use the language in the context of structured interpersonal exchange, in which many factors interact. This entails that a well-managed teaching of speaking skills will make students aware of the role played by the skill in enabling them to interact globally. Despite their importance, speaking skills are not up to the level they are expected to be and the causes for this in the EFL context needs investigation.

\section{Statement of the problem}

In Ethiopia, English language is taught as a subject starting from lower primary school (grade one). It is the medium of instruction in secondary schools and in higher education institutions (tertiary education- in universities or colleges). From primary school to college, students cover 10 to 12 years of learning English language. When they join teacher education colleges to train as a teacher, they had already learned English as a subject and as medium of instruction for about 12years and they are expected to have a good command of the language. According to the language policy of the country, students are expected to have good command of English language and they should have good communicative competence. They are supposed to communicate through speaking, reading, writing and listening at the end of secondary school (MoE, 2002).

However, the students come to colleges with deficient EFL proficiency in general and serious problems of speaking skills in particular. They also face problems of understanding when others speak, including their teachers, and are often seen switching to their vernacular language. Despite learning English Language for many years, the students' level of proficiency in speaking skills is daunting. Why does this happen very often? This burning issue makes it necessary to investigate the factors which contributed to the students' poor speaking skills. In addition, as far the knowledge of the researcher is concerned; researches conducted on this issue in the setting under consideration are very scanty. This indicates the presence of a research gap which needs to be filled. Therefore, it is found to be necessary to explore the factors which impede the EFL students' speaking skills in Jimma Teachers College.

\section{Research questions}

The research tried to address the following questions:

1. What are the main factors which affect EFL students' speaking skills in Jimma Teachers College?

2. What are the major problems of students in the speaking skills?

3. What are the causes of the students' problems in the speaking skills?

4. What are the roles of EFL teachers in the speaking class?

5. What are the activities which students do during the speaking class?

6. What are the major techniques used by the teachers in the speaking class to help students practice English?

\section{Objectives of the Study}

The main objective of the research was to investigate the factors which impede EFL students' speaking skills in Jimma Teachers College. Specifically, the research intended to:

1.Identify the major problems affecting students speaking skills

2. Find out the causes of students' speaking problems

3. Explore the techniques and strategies used by the EFL teachers to teach speaking skills. 
4. Identify if the teachers are aware of their own roles in speaking class.

5. Find out if the teachers motivate the students during the speaking lesson.

\section{Significance of the study}

The study is helpful in making the stake holders aware of the factors which pose problems to the students' speaking skills. It would in particular enable the EFL teachers to identify areas they should focus on to help their students to overcome their speaking problems. Over and above, the regional education bureau and the ministry of education can use the findings to devise strategies for addressing problems related to the teaching and learning of EFL classes and to assign well qualified teachers.

\section{REVIEW OF LITERATURE}

\section{The concept of speaking skills}

Speaking is an interactive process of constructing meaning which involves producing, receiving and the processing of information (Kayi, 2006). The forms and meanings of speaking rely on the context in which it occurs. This comprises of the participants of the speech, the background of the participants, the physical environment in which the speaking takes place and the purpose for which the speaking is conducted.

\section{Teaching and learning speaking skills}

Learning and teaching a language in general is aimed at scaling up people's ability of utilizing the language for communication purpose. The classroom process has to enable students to use the target language to get things done or to do something related to real life situation outside of the classroom using the language.

The skills of using the target language for communication or for real life situation in EFL context is dependent upon the condition in which the language has been taught or learnt in the classroom. EFL speaking skill develops when the students are encouraged to practice it using various authentic tasks in the classroom through the facilitative role of their teachers. These authentic tasks are tasks related to real life activities done by the language community in the real communication situation.

A large number of English as foreign language students often abhor or are scared of speaking English language. Because of lack of enthusiasm or motivation emanating from fear, EFL students mostly reveal an inactive role in the EFL speaking class. According to Eckard and Kearny (1981), this passive attitude towards participating in speaking lesson results from the students' lack of opportunity to express their ideas naturally and spontaneously. Scholars depict that EFL students' passive roles during the speaking class can be changed through the proper utilization of the varieties of speaking skills teaching strategies.

Cotter(2007), for instance, discloses that students' inactive role in the speaking class can be altered and improved through training on oral skills which makes the students capable of speaking and interacting in a meaningful and interactive way. According to this scholar, these incorporate activities such as exchanging information, negotiating meaning, supporting ideas, facing oral defense, and involving in debates. Utilization of such participatory activities is a method of encouraging and motivating students to understand EFL as a device for social interaction. The goal of teaching speaking in the EFL class is to enable the students to make use of English for various real life activities.

According to Chaney (1998), speaking is the process of building and sharing meaning through the use of verbal and non-verbal symbols in a variety of contexts. Hence, the teaching of speaking skills in EFL classroom has to improve students' communicative competence. This will enable the students to express themselves and to follow the social and cultural rules appropriate in each communicative circumstance. In order to help their students to improve their speaking skill, EFL teachers are expected to create a classroom environment in which students have real life purpose for communication, authentic activities and meaningful interactive tasks which develop students' speaking proficiency. In the process of learning EFL speaking skills, students also need to have an internal drive which enthuses them to practice the target language. It is through repeated practices which students can overcome the factors which often impede their learning to speak the target language.

Kayi (2006) indicates that "speaking is the gap between linguistic expertise and teaching methodology." This scholar depicts that linguistic expertise focuses on structure of language and content of language. On the basis of this fact, the teaching of speaking skill requires frequent practice. Teaching speaking is aimed at habit formation which leads to an actual communication. In the modern communicative language learning and teaching approach, the intention of teaching speaking is to prepare students for real communication. Real communication 
comprises of accomplishing tasks such as conveying a telephone message, getting information or expression of opinion and etc.

\section{Factors impeding EFL students' speaking skills}

Language teaching in general can be challenged by varieties of factors. Knowledge and awareness about these challenging factors can arouse the teachers to think of the ways to overcome them. If teachers are aware of the factors which impede their students' success in speaking skills, they may play a pivotal role in supporting learners overcome their problems of learning to speak. There can be different conditions which result in students' poor performance in speaking skills. Students' speaking performance can be affected by the factors that come from performance conditions and from the students themselves. Performance related conditions include time pressure, planning, standard of performance and amount of support, affective factors such as motivation, confidence and anxiety, listening ability and feedback during speaking activities. Factors from students themselves are referred to internal factors, and they incorporate native language, age, exposure, innate phonetic ability, identity and language ego, motivation and concern for good speaking (Brown, 2001; Harmer, 2007).

\section{Performance conditions}

Students perform a speaking task under a variety of conditions. According to Nation and Newton (2009), performance conditions can influence learners' speaking performance. These scholars indicate four categories of performance conditions. They are time pressure, planning, the standard of performance and the amount of support.

\section{Affective factors}

Learning a foreign language in general can be influenced by different factors. Affective factors are among the factors which impact the success of EFL learning (Oxford, 1990). In his affective filter hypothesis, Krashen (1982) states that a variety of affective variables can influence students' success in learning a second language (SL) or a foreign language (FL). According to Krashen (1982), the main affective factors influencing the learning or acquisition of FL or SL are motivation, selfconfidence and anxiety.

\section{Listening ability}

Speaking skill as a whole necessitates active interaction between the speaker and the listener. People speak to be understood or to convey certain message. Since there is exchange of ideas in the process of speaking, the ability of listening and understanding information conveyed during speaking is also vital. Listening and speaking are not mutually exclusive. Speaking skills cannot develop unless we develop listening skills (Doff, 1998). Students are supposed to understand what is said to them in order for a successful conversation to exist. In a similar token, Shumin (2002) states "when one person speaks, the other responds through attending by means of the listening process." In the process of conversation, where there is exchange of ideas between the speaker and the listener, every speaker plays the role of both a listener and a speaker. Therefore, a speaker or listener cannot respond unless he/she understands what has been said. This indicates how closely speaking skills and listening skills are interdependent.

\section{Topical (background) knowledge}

Factual knowledge, the world knowledge which learners bring to the world of language learning, plays a decisive role in enabling the students to be successful language learners. This factual knowledge is termed as topical or background knowledge. According to Bachman and Palmer (1996), topical knowledge is knowledge structures in long-term memory. In other words, topical knowledge is the speakers' knowledge of relevant topical information. It enables learners to use language with reference to the world in which they live. Bachman and Palmer (1996) state that certain language tasks may be easier for those who possess the relevant topical knowledge, and more difficult for those who do not have the topical knowledge. According to these scholars, students' background knowledge or topical knowledge has an impact on their speaking performance.

\section{Feedback during speaking activities}

Giving feedback to students in such a way that students will be aware of areas on which they have to work hard is a method of helping students to succeed in language learning. Accordingly, most students want their teachers to give them feedback on their performance. In spite of this, all speaking productions are not treated in the same way. According to Harmer (1991), the decisions that the teachers make about how to react to their students' performance will depend upon the stages of the lesson, 
the activities, the types of mistake made and the particular student who is making that mistake. This indicates that EFL teachers have to be systematic in giving feedback. Since errors are, in most cases, part of the students' learning progress, identifying areas which need more focus is of paramount importance. If the teachers try to correct whenever there is a problem, the conversational flow as well as the purpose of the speaking activity will be destroyed (Harmer, 1991). If the students are corrected all the time, they can find this very demotivating and become discouraged and are afraid to speak. According to Baker and Westrup (2003), EFL teachers should always correct the students' errors positively and with encouragement making the students aware that errors are part of their learning progress.

\section{Speaking problems}

In spite of the vitality of speaking skills for them in real life contexts, EFL students learning to develop their speaking skills in English may have some internal and external problems. The internal problem which may impede the students speaking skills is affective filter like the feeling of anxiety. When the students are in anxiety, they will be shy and afraid of speaking. This makes them unwilling to talk in the target language when they learn the skill. The fear of committing mistakes also makes them reluctant to practice speaking in English language (Nascente, 2001). To relieve their students from such situations, in the process of teaching speaking skills, the EFL teachers are supposed to create a suitable condition for students to interact confidently by overcoming the affective factors like anxiety. When they try to motivate their students to speak in class, teachers may face varieties of challenges. According to Ur (1996), EFL teachers often face some speaking problems in getting students to speak English in the classroom. Some of these problems are inhibition, lack of topical knowledge, low or uneven participation and mother-tongue use.

Inhibition is the first problem which students usually face. In the process of making efforts to speak in EFL, students are often reserved. They feel anxiety of making mistakes and fright of criticism. EFL students are afraid of the consideration which their talk in foreign language attracts. This usually makes them reluctant to practice to speak in English. In relation to this, Littlewood (2007) contends that a foreign language classroom can create inhibitions and anxiety easily on account of students' lack of confidence.

The other reason for students' complaint about their failure to speak is that they cannot think of anything to say and they have no encouragement and motivation to express them. According to Rivers (1988), learners have nothing to express or lack motivation to speak maybe because their interest and experience had not been taken into account during the selection of the topic of the speech. Students will be demotivated may be when the teacher chooses a topic which is not appropriate for the students or about which the students do not have much experience or knowledge. In such situation, it is difficult for students to respond when the teachers ask them to speak in EFL. This may be because the students lack ideas about what to say, which vocabulary to use, or how to use the grammar correctly (Baker and Westrup, 2003).

The third problem in speaking class is that students do not participate very well. Classroom participation is usually dominated by active students and most of the other students are silent. In the context of a large class, slow and average students will be engulfed and they will have very little talking time.

Eventually, in the classroom context where all students use the same mother tongue, they prefer to use their vernacular as they consider their mother tongue to be easier to use than the EFL. Concerning students' reasons to tend to use their mother tongue, Harmer (1991) indicates a few points. Firstly, when the students are asked to discuss a topic which they are not familiar with they will prefer to use their own language if they feel that they have nothing to say in the target language. Another reason is that using mother- tongue is a natural thing to do. Students who have the same L1 usually prefer to speak with each other using their mother tongue. Moreover, if the EFL teacher does not motivate the student to use English to speak, the students usually shift to their vernacular language. Finally, when the teachers use the students' mother tongue more often, the students will feel comfortable to use it as well and they do not bother about practicing or using the target language in an EFL classroom.

\section{METHODOLOGY}

\section{Study area}

The research was conducted in Jimma Teachers college which is located in Jimma Zone. Jimma Teachers college is found in Ethiopia in the South Western part of Oromiya National Regional State. Jimma town, where the college is found, is located 355 kilo metres to the west of Addis Ababa, the capital city of the county. Jimma Teachers College (JTC) was first established as teacher education institution in 1968 G.C. Since its establishment, the college had been training primary school teachers. Students who had completed their secondary school education at grade 12 used to be recruited to train as primary school teachers (teachers who used to teach from grade 1 to 6 by then) for one year. After taking teacher education courses for a year, they were awarded a certificate as lower primary school teachers. The institute had been giving such training until the end of 1996. This teacher education institute grew to the level of teacher Education College and began 
to train teachers who were expected to teach Junior secondary schools, grade 7 to 8,(as was called by then) in summer 1996 . Trainees who joined the college after completing secondary education at grade 12 used to take teacher education courses for two years and were awarded a diploma in teaching. This type of teacher education lasted for 8 years (from 1996 to 2003). With the implementation of the new education policy in Ethiopia (MoE,1994), in which secondary education was started to be completed in grade 10 , the college started to award a $10+3$ diploma to trainees who would be qualified as second cycle primary schools (grade 5 to 8 ). The students who joined the college to train as teachers after completing grade 10 have to undergone the teacher education courses for three years. After giving teacher education courses to the would be teachers for 3 years, the college awarded a teaching diploma. The diploma is called $10+3$ diploma as the students take teacher education courses for 3 years after completing their secondary education at grade 10 .

\section{Subjects/participants of the study}

The subjects of the study were EFL students and their teachers in Jimma teachers college. There were students who were attending teacher education course at different levels in the college. Among the students, second year EFL students were taken as the participants the study. The English language teachers who were teaching the students indicated were also taken as the subjects of the study. Both teachers and students were the participants used as the source of data or this research.

\section{Sampling technique and sample size}

The second year EFL students in the college were 200. In order to take the sample from the total population, the researcher used simple random sampling technique whereby he employed the lottery method. Among the total population, the researcher took 50 $\%$ as the subjects of the study. To select the teacher-informants, the researcher employed comprehensive sampling whereby the whole teachers were made to involve in the study. The total number of EFL teachers in the college during the study was 20; and therefore, all of them were made to participate in the research. The 20 EFL teachers were divided into two groups (each group with ten members) and participated in focus group discussion. Among the teachers, 25\% were randomly selected and observed while teaching speaking skills in their class. The sample size in general was 120 (100 students and 20 teachers).

\section{Instruments of the research}

In order to gather the necessary data for this study, the researcher employed questionnaire, focus group interview and classroom observation.

\section{Questionnaires}

Questionnaire was one of the data collection tools utilized in this research. According to Kothari (2004), questionnaire is a tool which enables researcher to collect data from a large number of informants in a short period of time. In addition it is free from the researcher's bias as the respondents can fill the questionnaire on their own. The questionnaire used to collect data for this research had two sections. The questionnaire was filled by the 2nd year EFL students. A questionnaire consisting of 15 items was prepared and distributed to the sample second year EFL students in Jimma Teachers College. The questionnaire was aimed at gathering information about the factors impeding the students' speaking skills. It had twelve close ended and three open ended items. The questionnaire tried to identify the causes of the EFL students' problems in speaking skills. In addition, it aimed collecting data on the students' practice of speaking and their level of speaking proficiency. Furthermore, the questionnaire focused on techniques used by teachers and students in speaking class.

\section{Focus group discussion (FGD)}

Focus group discussion (FGD) was the other instrument used to collect data for this research. Unstructured FGD guide was used with the EFL teachers to get thorough and deep information about their classroom practices during the teaching of speaking skills. The FGD was conducted with two groups of EFL teachers consisting of 10 members (each FGD had 10 members). It was mainly intended to find out information on how the teachers taught speaking skills, problems they faced, factors affecting the students' speaking skills, and the strategies they employed to teach the skills.

\section{Classroom observation}

The classroom observation was used to explore activities which were done by the students during the speaking lesson. It was also aimed at finding out the real classroom practices of the EFL teachers. The observation was intended to substantiate the data which were gathered from the EFL teachers by using questionnaire and FGD. The observation checklist which was prepared focused on activities in which the students were involved during the speaking lesson, speaking problems faced by the students and techniques, strategies and tasks used by the EFL teacher to teach speaking skills.

\section{Procedures of data collection}

Prior to colleting the data, the researcher had a short discussion with the dean of Jimma Teacher Education College. During the discussion, the researcher explained about the research and its aims to get permission for the investigation. Having obtained letter of consent from the college dean, the researcher did pilot study. The questionnaires were pilot-tested to students who were not made part of the main investigation. After piloting the items, the researcher made some improvements on the instructions and the language in order that the participants could understand and give the required information. Some changes were also made on the contents of the items based on the results of the pilot study. Thereafter, the researcher talked to the teachers and arranged the time for filling the questionnaire, to conduct FGD and to do classroom observation. An unstructured guide was prepared and used for the FGD. In addition an observation checklist with 5 items was prepared and filled during the observation. The researcher and his co-observer observed five EFL teachers. Each teacher was observed two times while teaching speaking skills to the students. This was done to investigate what the real speaking classroom situation looked like and what the students' and the teacher were doing during the speaking lesson. 
Table 1. The EFL skills in which students faced more challenges.

\begin{tabular}{llcc}
\hline Question & Response & Frequency & Percentage (\%) \\
\hline & A/speaking & 80 & 80 \\
& B/writing & - & - \\
In which of the following Language skills do you face more problems? & C/Listening & 6 & 6 \\
& D/Reading & - & - \\
& E/All but D & 10 & 10 \\
& F/All & 4 & 4 \\
& Total & 100 & 100 \\
\hline
\end{tabular}

\section{Method of data analysis}

The researcher employed mixed approach to analyze the data. Both qualitative and quantitative methods of analysis were used. The data from questionnaire were analyzed quantitatively and this was done based on tables of frequency and percentage for the close ended items. The data which were collected from FGD, open ended items in the questionnaire and classroom observation were analyzed qualitatively. These data were transcribed and narrated thoroughly.

\section{RESULTS AND DISCUSSION}

The participants were inquired to fill in questionnaire regarding the factors which impeded students' speaking skills. The analysis of the data was indicated as follows:

According to the data in Table $1,80 \%$ of the students faced serious problems in speaking skills. As indicated in the table, the difficulty which the students faced in the other language skills is less as compared to speaking skills. It was found out that only $6 \%$ of the students faced problems in learning listening skills. The other $14 \%$ stated that they faced problems in all skills. Among the $14 \%$ of the respondents, $4 \%$ revealed that they faced problems in all EFL skills except reading skills. It possible to understand from the table that speaking skill was the skill which the EFL students in the college found more difficult.

As can be understood from the data in Table 2, the major factors which affected the students' speaking skills were lack of exposure to English in and out of school, lack of motivation, students' poor background, fear of making mistakes. The finding indicated that $60 \%$ of the respondents have problems of speaking skills because of these factors. According to the data, among the respondents, $12 \%$ indicated that their speaking skill was affected by fear of making mistakes. The other $10 \%$ indicated that their speaking skill was influenced by lack of motivation to learn it. Respondents who pinpointed that speaking skill is affected by lack of exposure to English language in and out of the class were $11 \%$.

The finding of the research in Table 3 indicated that a large number of the students did not often practice speaking English Language. As can be understood, 85\% of the informants stated that they did not often practice speaking English language. Only 15\% of the students stated that they practiced speaking skills. From this data it is evident that the EFL students in the college lack frequent practice in their speaking skills. The respondents revealed that speaking is not often practiced because of various reasons.

The data in Table 3 also reveals that the students did not often practice speaking skills because of various reasons. The main reasons which impeded the students' speaking practice were the inadequate talking time given to them by their teachers during the lesson, the teachers' frequent use of the students' mother tongue to explain ideas during the lesson, and shortage of adequate speaking tasks during the speaking lesson respectively. According to the data, $48.2 \%$ of the respondents revealed that they did not often practice speaking as the speaking class is teacher-dominated and the students did not have the chance of talking. This implies that the speaking classes are teacher centred. In other words, teacher's talking time (TTT) is longer than students' taking time (STT) and the students have a passive role of listening in most of the speaking classes.

Similarly, about $25 \%$ of the respondents stated that they did not often practice speaking as their teachers used the students' vernacular language during the speaking lesson. The other $9.4 \%$ of the respondents indicated that they did not often practice speaking because there are no English speakers in the surrounding and in the school. Still the other 5.9\%' pointed out that they did not often practice speaking skills because of fear of making mistakes as their friends may ridicule them. Among those who stated that they often practiced speaking skills, $60 \%$ pinpointed that they did so rarely.

Similarly, $27 \%$ of the respondents indicated that they 
Table 2. Factors affecting EFL students' speaking skills.

\begin{tabular}{llcc}
\hline Item & Response & Frequency & Percentage (\%) \\
\hline & A/ Lack of much exposure to English in and out & 11 & 11 \\
& of school & 6 & 6 \\
What are the main factors which affect & B/ Poor background & 10 & 10 \\
your speaking skills? & C/Lack of motivation & 1 & 1 \\
& D/l not interested in English & 12 & 12 \\
& E/ Fear of making mistakes & 60 & 60 \\
\hline & F/ All & 100 & 100 \\
\hline
\end{tabular}

Table 3. Practice of speaking skills.

\begin{tabular}{llcc}
\hline Item & Response & Frequency (f) & Percentage (\%) \\
\hline \multirow{2}{*}{$\begin{array}{l}\text { Do you often practice speaking English } \\
\text { Language? }\end{array}$} & Yes & 15 & 15 \\
& No & 85 & 85 \\
& Total & 100 & 100 \\
& Since English is not used in and out of class & & 8 \\
& ,there is no chance to practice it & 8 & 10 \\
& speaking tasks given in class are very less & 10 & 21 \\
If your answer to question No.3 is 'No', & My teachers often use my L1 when they & 21 & 41 \\
which of the following is your main & teach and I do so & & \\
reason? & My English teachers take most of the talking & & \\
& time and I always listen to them; there is no & 41 & 100 \\
& opportunity to practice & & \\
& I am afraid of speaking English since my & 5 & 7 \\
If your answer to question 'No. 3' is yes, & Sometimes & 85 & 27 \\
how often do you practice speaking in & Rarely & & 60 \\
English class? & Total & 1 & 7 \\
& Never & 4 & 100 \\
\hline
\end{tabular}

sometimes practiced speaking skills. Even though these respondents said that they often practiced speaking, the result in this table reveals that they did not practice it very often.

Only $7 \%$ of the respondents stated that they practiced always. It is possible to understand from this finding that most of the time; the students do not practice speaking skills.

The data in Table 4 indicates that teacher education college students fail to express themselves in English in spite of learning it for many years. The major cause for this was lack of opportunities to use English in real life situations in and out of the classroom compound. This had affected their motivation. The total percentage of the informants who indicated this was $62 \%$. The other main cause of speaking problems indicated by the informants was mother tongue domination. This reveals that the students did not have wider chance of using English language in their daily life activities. They had more access to the use of their mother language than to English language for communication as a whole. It can be inferred from this finding that domination of mother tongue has resulted in the students' failure to speak English to the level expected of them. In addition, the 
Table 4. Causes of EFL students' speaking problems.

\begin{tabular}{|c|c|c|c|}
\hline Item & Response & Frequency (f) & Percentage (\%) \\
\hline \multirow{6}{*}{$\begin{array}{l}\text { Most of the time, students like you, do not } \\
\text { want to speak English even after learning } \\
\text { it for many years. What do you think is the } \\
\text { cause for this problem? }\end{array}$} & $\begin{array}{l}\text { English is not the medium of instruction } \\
\text { in primary schools }\end{array}$ & 7 & 7 \\
\hline & $\begin{array}{l}\text { Lack of positive expectations about } \\
\text { English language }\end{array}$ & 6 & 6 \\
\hline & Difficulty of English Language & 5 & 5 \\
\hline & $\begin{array}{l}\text { Lack of opportunities to use English in } \\
\text { the real life situations (in and out of } \\
\text { school) }\end{array}$ & 62 & 62 \\
\hline & Mother tongue domination & 20 & 20 \\
\hline & Total & 100 & 100 \\
\hline
\end{tabular}

Table 5. Frequency of doing speaking tasks in English class.

\begin{tabular}{llcc}
\hline Item & Response & Frequency (f) & Percentage (\%) \\
\hline & Always & 0 & 0 \\
How often do you do activities/tasks to develop your & Sometimes & 5 & 5 \\
speaking skills in English class? & Rarely & 7 & 7 \\
& Never & 88 & 88 \\
& Total & 100 & 100 \\
\hline
\end{tabular}

data in the table revealed that the fact that English language is not the medium of instruction in Ethiopian primary schools, the students' expectation about learning English language, and the level of the difficulty of English language respectively contributed to the students' failure in speaking skills to a lesser degree.

According to the data in Table 5, the students did not often involve in doing activities/tasks which help to develop their speaking skills. As can be understood from the table, $88 \%$ of the students showed that they never did speaking tasks in English class. Only 5\% of the respondents indicated that speaking tasks are done sometimes. In addition, $7 \%$ of the respondents stated that they rarely did speaking tasks. As can be understood from table 6 , the students' speaking class was dominated by dialogue and group work.

According to the data $62 \%$ of the respondents indicated that they did dialogue in the speaking class. The other $29 \%$ revealed that they did group work in speaking class. It is evident from this finding that most of the activities which are helpful for developing the students' speaking skills were overlooked. Students were not often given speaking tasks like role play, journalistic interview, presentation, drama, debate, and problem solving, debate, speech presentation, problem solving activities and drama. As shown in Table 7, the motivational role of the EFL teachers during the speaking lesson was less. The respondents pointed out that the teachers did not motivate them most often. It can be understood from the table that more than half of the respondents, $54 \%$, stated that their teachers never motivated them to speak in class. Only $25 \%$ showed that EFL teachers sometimes motivated the students. The other $19 \%$ of the respondents stated that the EFL teachers motivated the students rarely. From this data it is possible to figure out that students were not motivated by their teachers in most cases.

According to the data in Table 8, the main roles of EFL teachers in speaking class were telling the students about the expressions they have to use to speak or ask for things(27\%), explaining to students how to speak to get things done in English(24\%), and teaching the about speaking (22\%) respectively. One can understand from this data that the teachers were involved in teaching about speaking; not in teaching the students to speak. The main roles which teachers could have played to help their students to develop their speaking skills like motivating learners to speak, facilitating speaking tasks, encouraging students to participate in speaking activities, giving them various speaking tasks, and organizing pair and group work were not given much emphasis by the EFL teachers in English class. 
Table 6. Tasks/activities given by the teacher in speaking class.

\begin{tabular}{llcc}
\hline Question & Response & Frequency (f) & Percentage (\%) \\
\hline & A/ Role play & 3 & 3 \\
& B/ speech presentation & 0 & 0 \\
& C/ dialogue & 62 & 62 \\
Which of the following tasks do your teachers give & D/Group work & 29 & 29 \\
& E/ Drama & 1 & 1 \\
you in the speaking class? & F/ Interview & 2 & 2 \\
& G/problem solving & 0 & 0 \\
& F/ Debate & 3 & 3 \\
& Total & 100 & 100 \\
\hline
\end{tabular}

Table 7. The rate of EFL teachers' motivation in speaking class.

\begin{tabular}{llcc}
\hline Question & Response & Frequency (f) & Percentage (\%) \\
\hline \multirow{4}{*}{ How often do you do your English teachers motivate you } & Always & 2 & 2 \\
to speak in class? & Sometimes & 25 & 25 \\
& Rarely & 19 & 19 \\
& Never & 54 & 54 \\
& Total & 100 & 100 \\
\hline
\end{tabular}

Table 8. The role of EFL teachers in speaking class.

\begin{tabular}{llcc}
\hline Question & Response & Frequency (f) & Percentage (\%) \\
\hline & Explaining how to speak to get things done & 24 & 24 \\
& Teaching us about speaking & 22 & 22 \\
& Organizing pair and group work & 13 & 13 \\
Which of the following things do your & Motivating us to speak & 7 & 7 \\
teachers do most during the speaking & Facilitating our speaking tasks & 0 & 0 \\
class? & Encouraging us to participate in speaking & 5 & 5 \\
& Giving us various speaking tasks & 2 & 2 \\
& Telling us the expressions we use to speak or ask & 27 & 27 \\
& for things & 100 & 100 \\
\hline
\end{tabular}

Results from the open-ended items of the questionnaire

\section{Speaking activities done by students during the lesson}

The result of the interview and classroom observation indicated that pair dialogue and group discussions were the main activities in which the students were involved during the speaking lesson. The teacher gave the students prepared dialogue and told them to memorize and practice in pairs. In addition he gave them a topic and told them to discuss in group of 5 . During the group work, the teacher was standing in front of the students and waiting for them to finish the discussion. The classroom observation revealed that most of the students were off task and talking about personal issues in their mother tongue. The teachers were not monitoring the students work and they made no efforts to motivate their students. This implies that the roles played by the EFL teachers in the speaking classes to encourage the students to practice speaking poor were and inactive. 


\section{The major techniques used by the teachers in speaking class}

The result of the study revealed that dialogue practice and group discussions were the only techniques used by the English teachers to promote speaking skills in class.

\section{Challenges faced by students in learning speaking skills}

The students indicated as the main challenge that the fact that all other subjects they learn in the college except EFL are in their local language. They stated that this has mitigated their opportunities of practicing English as a whole. They added that their poor background in English from the lower levels is another challenge. According to their response to this open ended item, the students clearly stated that they did not get wider chance to use English and this has affected their speaking skills. A student stated the following in the response given:

Until I reached grade nine, I was learning all subjects in my mother tongue. I remember English as one of my classroom subject only when I English Language comes to class. Other times all subjects are taught in the local language. English was given as foreign language. It was not a medium of instruction. I began to learn all subjects in English when I joined grade 9. When I passed to grade nine where English is a medium of instruction, my English had already been crippled. Having completed grade 10, I joined Teacher education college (TEC) where all students in department other than English are taught all subjects in local language. This has made my opportunity of using English less. My poor background has continued to live with me.

This indicates that the students join TEC with poor background and their proficiency in speaking skills is below the expected standard. In a similar token, another student explained the following point for the open ended question:

I thing of and remember about English when English period comes and when I do my English homework. My teachers, even at this college level, use my vernacular, to teach me and to communicate with me. The opportunity which I have to interact with people in English is almost zero. I don't have motivation to speak English as I can easily get things done in my mother tongue in and outside of the classroom. There is no one who uses English outside the classroom. My English teacher also explains most of the points my mother tongue. Personally, I love to practice speaking English. However, when I try to speak it, my friends laugh at me and call me braggart. Therefore, I prefer not to speak it in order not to be ridiculed by my classmates. Moreover, my poor background from primary and secondary schools has affected me a lot.

\section{Results from FGD}

The researcher used FGD to collect data from the EFL informants. As had already been indicated, two FGD consisting of 10 members each was organized and used. The FGD with the teachers also indicated the presence of serious speaking problems among the students. The result of the FGD showed that students' speaking problems were caused by their lack of opportunity to use English Language outside the classroom. In addition, it was found out that the students were learning the other subjects in local language from grade 1-8 and using English language is confined to the English class alone. The EFL teachers' FGD indicated that this factor had made the students' chance of practicing to speak English very limited. One of the FGD participants in particular, stated the following:

My students remember English Language only when I go to the class. English language is classroom limited and the students won't find it in their real life contexts outside. The community in the college and elsewhere in the town do not use it. English is not an official language and there is no compulsive situation for students to practice English. Even EFL teachers are usually translating the content of English courses to the students' mother tongue in the name of helping them understand well. This has discouraged the students from making efforts to practice and improve their English. I personally think that the status of students speaking skills in the college in general is going worse and worse. (FGD1 Participant 7)

Concerning the low level of the students' speaking skills, the EFL teachers revealed that the students themselves were responsible. A participant of the FGD stated the following:

I think we students are also responsible for our own learning. We have to work hard and use English alone to improve our skills. Our main problem is we use our local language when our English teacher gives us group work. We have to commit ourselves to practice using English in every way possible. (FGD 2 Participant 3)

Regarding the students' poor and deteriorating level of speaking skills and its causes, the FGD participants had a closer thought. Almost all of them disclosed that the 
main causes of the students' speaking problems are the following:

1. Lack of opportunity to practice English

2. Teachers speak most, and students listen to them

3.Teachers use the students' mother tongue (L1) to explain ideas instead of using only English

4. Lack of motivating conditions to use English outside of the classroom

5. Classroom speaking lessons are teacher - dominated

6. There is no extra/additional support out of the classroom lesson

\section{Results from classroom Observation}

The result of the classroom observation indicated that there were no many communicative tasks which encourage oral interaction. The teachers totally depended on pair dialogue and group discussion. Despite the vitality of utilizing various techniques to teach speaking, the English teaches were observed using only group discussion for which the students were given a topic. They made the students memorize dialogue and act it out in pairs. This had lessened the students' opportunity of practicing speaking skills. During the observation, both the English Language teacher and the students were using the local language to express ideas and concepts. In most cases, the students had passive roles when the teacher taught speaking skills as lectures about speaking skills were given by the teachers. The speaking class was dominated by the teachers talking time while the students were made to listen carefully to what the teacher teaches. The observation indicated that techniques and strategies which are helpful in teaching speaking skills (role play, information gap, journalistic interview, drama, debate, etc.) were not used by the EFL teachers during the speaking lessons. This indicates that the way the teaching of speaking skills was managed by the teachers was one of the impeding factors for the students speaking skills development.

\section{DISCUSSION}

The findings indicate that speaking is the language skill in which the students have serious problem. The main factors which impede students' speaking skills were lack of much exposure to English in and out of school, poor background, lack of practice and fear of making mistakes. In addition, lack of exposure to adequate techniques of learning speaking has affected the students speaking skills. On account of lack of practice, the students' level of speaking skills is very low. Despite learning English language for more than 10 years, the students could not express their ideas in English through speaking. The result of the research indicated that the main reasons for this were lack of opportunities to use English in the real life situations and the influence or domination of mother tongue in the college classrooms.

The research also indicated that the classroom teachers often took most of the talking time in the class and the students were passive listeners. According to Rivers (1988:9), "teacher directed and dominant classrooms cannot by their nature be interactive classrooms and this is what a language teacher needs to learn." Rivers emphasized that classroom interaction can be three way or flour way but it can hardly be one way. This indicates that a classroom dominated by the teacher does not help students to develop their speaking skills.

It was found out that the English teachers used the students' L1 (local language) to explain ideas and concepts instead of using English alone. The teachers did not try to make themselves a role model for the students by using English. This had affected the students' motivation to try to use English. The students used their mother tongue for discussion during group work and when they practiced the dialogue give to them by their teachers. The teachers did not go around to monitor the students' activities. In addition, the teachers did not use most of the activities which are helpful to develop the students' speaking skills. Furthermore, the EFL teachers did not give additional supports to the students to develop speaking skill. The finding indicated that the teachers used only group work and dialogue to teach speaking. However, in order for the students to develop communicative competence or efficiency in speaking, classroom teachers are expected to utilize a balanced activities approach which incorporates language input, structured output, and communicative output (Nunan, 2003).

\section{Conclusion}

English Language is taught as a subject in Ethiopia starting from grade 1 . It is a medium of instruction in secondary schools and in Universities. The students under investigation have been learning English Language for 10 to 12 years. However, they have a serious problem of expressing their thought in English Language. Based on this ground, the study was aimed at exploring the factors which impede the students' speaking skills. The results of the research indicated that the main factors which impede the students' speaking skills were lack of exposure to English Language in the real life context, lack of practice, poor background, and lack of adequate access to various techniques which help to develop speaking skills, mother tongue dominance/influence, and 
lack of good role models. It had been suggested that the English Language teaches have to create a conducive situation to use various techniques and strategies to develop the students speaking skills. Further researches focusing on issues related to the teaching speaking skills have to be done.

\section{RECOMMENDATIONS}

1). EFL teachers should create conducive environment in the classroom so that the students' speaking skills can improve.

2). EFL teachers have to give activities which encourage real life speaking practice.

3). Students should be made to involve in activities like drama, debate, role play and presentations so as to improve their oral skills.

4). EFL teachers should commit themselves to encourage students to speak English in and out of the class by making themselves a role model.

5). The EFL teachers should minimize the utilization of the students first (local language)and encourage the students to try to use English during the speaking class.

\section{CONFLICT OF INTERESTS}

The authors have not declared any conflict of interests.

\section{REFERENCES}

Bachman LF, Palmer AS (1996). Language testing in Practice. New York: Oxford University Press.

Baker J, Westrup H (2003). Essential Speaking Skills: A Handbook for English Language Teachers, London: Continuun International Publishing.

Baruah TC (1991). The English Teacher's Handbook. Delhi: Sterling Publishing House Brown D (2001). Teaching by Principle. Pearson Education, Inc.

Brown G, Yule G (1983). Teaching the Spoken Language. Cambridge: Cambridge University Press.

Bygate M (1991). Speaking. Oxford: Oxford University Press.

Celce-Murcia M (2001). Teaching English as a Second or Foreign Language (3rd ed). USA: Heinle \& Heinle.

Chaney AL, Burk TL (1998). Teaching Oral Communication in Grades K-8. Boston: Allyn \& Bacon.

Cotter C (2007). Speaking well - four steps to improve your ESL EFL Students' Speaking Ability.Retrieved from: http://ezinearticles.com/?Speaking-Well----Four-Steps-To-ImproveYour-ESL-EFL-Students-Speaking- Ability \& id=631232

Doff A (1998). Teach English: A training Course for Teacher. Cambridge University Press.

Eckard R, Kearny M (1981). Teaching Conversation Skills in ESL. Language in education: Theory and Practice. Retrieved from: http://www.eric.ed.gov/ERICWebPortal/custom/portlets/recordmini.jsp ?_nfpb=true\&_\&ERICExtSearch_SearchValue_0=ED208676\&ERICE xtSearch_SearchType_0=no\&accno=ED208676
Elaine T (2005). Speaking in a Second Language- Handbook of Research in Second Language Teaching and Learning, Lawrence Erlbaum Association, Inc., Publishers.

Farooqui S (2007). Developing Speaking Skills of Adult Learners in Private Universities in Bangladesh: Problems and Solutions. Australian J. Adult Learn. 47:1-15.

Harmer J (2007). How to Teach English. Edinburg. Longman.

Harmer J (1984). The Practice of English Language Teaching. London: Longman.

Jack C, Willy A (2002).Teaching Speaking". Methodology in Language Teaching: An Anthology of. Current Practice CUP.

Kang S (2002). Factors to Consider: Developing Adult EFL Students' Speaking Abilities England: CUP

Kayi H (2006). Teaching speaking: Activities to promote speaking in a second language. TESOL 11(12):1-6.

Karahan F (2007). Language attitudes of Turkish students towards the English language and its use in Turkish context. Retrieved from: http://jas.cankaya.edu.tr/jas7/07-FIRDEVSKARAHAN.pdf

Kothari CR (2004). Research Methodology: Methods and Techniques $\left(2^{\text {nd }}\right.$ Revised ed.). New Delhi: New Age International Publishers.

Krashen S (1982). Principle and Practices in Second Language Acquisition. Oxford Press.

Littlewood W (2007). Communicative Language Teaching. Cambridge: Cambridge University Press.

McDonough J, Shaw C (2003). Materials and Methods in ELT: a teacher's guide. Malden, MA; Oxford: Blackwell.

MoE (2002). The Education and Training Policy and Its Implementation. Ethiopia: Addis Ababa Press.

MoE (1994). Federal Democratic Republic Government of Ethiopia Education and Training Policy. First Ed.Addis Ababa.

Nagaraj G (2008). English language teaching: Approaches, methods, techniques. Orient Blackswan, New Delhi.

Nascente R (2001). Student anxiety. English Teaching Professional. pp. 18-20.

Nation ISP, Newton J (2009). Teaching ESL/EFL Listening and Speaking. New York: Routledge.

Nunan D (2003). Practical English Language Teaching.NY:McGraw-Hill.

Staab C (1992). Oral language for today's classroom. Markham, ON: Pippin Publishing.

Ramirez VAC (2010). Students' Perceptions about the Development of their Oral Skills in English as a Foreign Language Teacher Training Program. Retrieved from http://repositorio.utp.edu

Richards JC, Renandya WA (2002). Methodology in language teaching. New York: Cambridge University Press. http://dx.doi.org/10.1017/CBO9780511667190

Rivers W (1988). Interactive Language Teaching. Cambridge: Cambridge University Press.

Shumin K (2002). Factors to consider: Developing adult EFL student speaking abilities. In: J.C. Richards \& W, Renandya (Eds.), Methodology in language teaching: An anthology of current practice ().Cambridge: Cambridge University Press. http://dx.doi.org/10.1017/CBO9780511667190.028 pp. 204-211

Ur P (1996). A Course in Language Teaching: Practice and Theory. Cambridge: Cambridge University Press.

White J (2004). Speaking, listening and learning materials. Qualifications and Curriculum Authority and the National Literacy Strategy Journal. Retrieved from http://www.literacytrust.org

Widdowson H (2003). Defining Issues in English Language Teaching. Oxford: OUP. 